International Journal of Social Sciences and Humanities
Available online at http://sciencescholar.us/journal/index.php/ijssh
Vol. 3 No. 3, December 2019, pages: $18 \sim 27$
e-ISSN: 2550-7001, p-ISSN: 2550-701X
https://doi.org/10.29332/ijssh.v3n3.342

\title{
Assessment of Information and Communication Technology Application in the Teaching of Office Technology and Management Students in Delta State Polytechnics
}

Emehi Akpomedaye ${ }^{\text {a }}$

Article history: Received 27 April 2019, Accepted: 31 August 2019, Published: 27 September 2019

\section{Correspondence Author ${ }^{\text {a }}$}

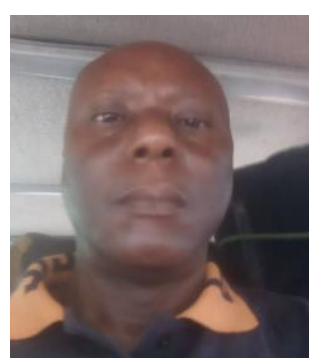

\section{Keywords}

graduation;

management;

office;

students;

technology;

\begin{abstract}
This study was designed to assess Information and Communication Technology (ICT) application in the teaching of Office Technology and Management (OTM) students in Delta State Polytechnics. Three research questions were raised to guide the study while two null hypotheses were tested at 0.05 level of significance. The study adopted a descriptive survey design. The entire population of 285 ND II and HND II students of Office Technology and Management program in the three polytechnics in Delta State were used for the study. Data was collected for the study through the administration of validated questionnaire on the respondents. Pearson Product Moment Correlation was used. The mean statistics was used to answer the research questions. The findings of the study revealed that Office Technology and Management students in polytechnics in Delta State are equipped to a high extent with information and communication technology in the areas of word processing and webpage design while they accepted low extent of application of database management system in the teaching of OTM courses in Delta State Polytechnics for job preparation. The implications of the findings have been discussed and conclusion drawn. Relevant recommendations were made towards the improvement of quality of office technology and management in polytechnics in Nigeria which include that database application and other ICT packages in the OTM curriculum should be emphasized in order to equip students with the competencies that will ensure effective work performance on graduation.
\end{abstract}

e-ISSN: 2550-7001, p-ISSN: 2550-701X ๑ Copyright 2019. The Author. SS Journals Published by Universidad Técnica de Manabí. This is an open-access article under the CC BY-SA 4.0 license

(https://creativecommons.org/licenses/by-sa/4.0/) All rights reserved.

a School of Business Studies Delta State Polytechnic, Ozoro, Nigeria 


\section{Contents}

Abstract

1. Introduction

2. Materials and Methods .

3. Results and Discussions

4. Conclusion .

Acknowledgments..

References

\section{Introduction}

The term "Office Technology" is generally considered to refer to the use of integrated computer and communication system to support administrative procedures in an office environment.

In the first half of the $20^{\text {th }}$ century in Nigeria, Office functions were carried out by manually operated machines, and work was timely completed due to small volume of work. As time went on, the need for secretarial and other quantitative records keeping tasks began to increase in volume, due to increased economic activities in the country. Consequent upon this, there was the used for different types of automated equipment to be used for the effective performance of office functions. The office has been and still remains designated as a place where clerical functions are performed, data processed and information is being managed. The growing relevance of the office is due largely to the information explosion that is taking place in society. The human ability and capability alone were now insufficient to cope with the performance of these office functions (Adetunji et al., 2017).

Currently, the world is moving to a completely paperless office that requires all information to be created stored electronically and transmitted. The advancement in technology has helped to enrich and broaden the science of secretarial practice in terms of speed, accuracy, and variety also known as automation of office functions. Office automation means the use of the computer and other electronic devices to perform office functions. Reproduction machines, dictating and storage machines, printers and copiers, fax, microfilm, electronic mail, voice mail, teleconferencing, and telecommunicating machines, make efficient performance of office tasks possible.

Globally, the teaching and learning of OTM education are drastically changing as a result of increasing interaction from telecommunication network via internet. Since technology is becoming an important issue in education, there is a need to replace the traditional pedagogical practices that will hinder these processes.

According to UNESCO (2004), ICT is defined in three ways. First, as technology. The application of information technology to the society; second, as the science dealing with the design, realization, evaluation, use and maintenance of information processing systems, including hardware, software, organizational and human aspects and the industrial, commercial, government and political implication of these, and third, as the combination of information technology with other related technologies. UNESCO adds that "these three definitions of ICT, which implies that ICT will be used, applied and integrated into activities of working and learning". Brenna \& Mashon (2002), assert that ICT is a term commonly used to describe the use of computers and related equipment to produce, store, manipulate, print, receive and transcribe information in electronic form, whether it is test, pictures, sound, videos, or other data. They further state that the ease with which large amount of information can be processed electronically and the speed and convenience with which it can be rented from place to place or even around offices located in various places, towns, and countries (world) has given rise to "the information superhighway".

Chikhamenar cited in Abonyi (2014), defined ICT as the acquisition, processing, storage and dissemination of information by means of a computer, office machines, and telecommunication. He further pointed out that the computer provides the processing, storage, and retrieval, for the transfers or communication of data and information.

According to Iloanusi and Osuagwu in Ede (2010), they opined that information communication technology (ICT), is the processing and maintenance of information and the use of all forms of computer, communication network and mobile technologies to mediate information. Simply, Adebaye in Egbe (2010),

Akpomedaye, E. (2019). Assessment of information and communication technology application in the teaching of office technology and management students in delta state polytechnics. International Journal of Social Sciences and 
posited that ICT covers the use of computers, radio, satellites, online self-learning packages, telepresence system interactive CDS, video, internet, optical fibre, technologies and all types of information technology (IT) hardware and software. Annan (2005) referred to the internet as holding the greatest promise humanity has ever known for long-distance and universal access to quality education.

According to NBTE (2004), the aim of OTM program, among others, is to equip students with effective work competence to fit properly into any office of an organization and carry out efficiently, the duties of a secretary which among others include the functions of the office to the entire organization, attending meetings providing information as may be needed. Others include making accurate records of processing, filing and retrieving of information, taking appropriate steps independently when faced with challenges in the office. It is expected that the secretary will show personal qualities and attributes conducive to tolerance and co-existence with the workgroup. The curriculum focuses on combining office information technology skills with adequate and relevant business or knowledge in solving organizational challenges.

What the above statement points to is that office technology and management students are expected to be equipped to be with relevant skills and competencies in computer and other electronic gadgets required to function effectively, in the modern office.

Emehi (2017), posited that the use of ICT packages such as access, computer-assisted instructions (CAI), PowerPoint, Webpage design, Desktop Publishing, etc in educational setting by itself, acts as a catalyst for change and learning of OTM courses in our institution of higher learning, Delta State in particular and the world in general (Mora \& Triana, 2018).

Database management system, a tool for learning OTM courses, is a collection of programs that enable the creation and manipulation of a database. An example of a database management system is Microsoft Access (MS Access) (Briones et al., 2016).

MS Access provides security features that prevent unauthorized users from trying to gain access to confidential database information and loss of data in case of a system crash. Lawrence (2010) asserted that MS Access is among the database applications being used mainly in offices, banks, and companies.

Furthermore, webpage design is also included in the OTM program for job preparation of students. Websites are created using a mark-up language called HTML, web designers build web pages using HTML tags that define the content and metadata of each page. The layout and appearance of the elements within a webpage are typically defined using CSS or cascading style sheets. Therefore, most websites include a combination of HTML and CSS that defines how each page will appear in a browser while the terms web design and web development are often used interchangeably, web design is technically a subset of the broader category of web development.

According to Nweke (2013), he averred that ICT facilities and applications for the training of OTM students in many polytechnics in the Southern part of Nigeria are grossly inadequate for OTM graduates to face the challenging demands of the new face of technology that keep unfolding ceaselessly. This implies that there may be no relationship between job preparation in schools and on the job activities. As offices globally are undergoing drastic changes on frequent basis owing to the emergence of ICT and related technologies, no organization, public or private working with these technologists would want to offer appointment to graduates of OTM with only manual typing skills. The need to apply ICT application for job preparation of OTM students is not only a challenge to the different institutions of higher learning, also a task that needs to be accomplished at all levels, especially ND, HND and degree levels. It is undoubted that the extent of use of information and communication technology application for job preparation of office technology and management program students has remained uncertain; a situation which this study seeks to assess.

\section{Statement of the Problem}

The introduction of office technology and management program with emphasis on information and communication technology applications for instruction was intended to prepare competent OTM graduates who would function effectively in information technology-based organizations and institutions. To be employable or efficient in an automated office, Ihimekpen (2009), recommended that OTM graduates must be well versed in various computer applications and knowledgeable in the use of modern office gadgets. Despite the role government and our educational institutions on the provision of ICT in the educational system, the performance of OTM graduates ability towards exhibiting the ICT skills is something to worry about. 
The question now is, whether the Nigerian polytechnic has appreciated the role of ICT packages in the teaching and learning of OTM courses? Do OTM educators actually recognize the ICT role in delivery OTM courses to OTM students? It is with this backdrop that this study on assessment of the use of ICT applications for job preparation of office technology and management students in polytechnics in Delta State is embarked upon.

Specifically, the study seeks to:

a) Ascertain the extent to which word processing application is utilized for instructional delivery in Delta State Polytechnics

b) Determine the extent to which database management application is utilized for instructional delivery in Delta State Polytechnics

c) Ascertain the extent to which webpage design application is used for instructional delivery.

\section{Materials and Methods}

\section{Research Questions}

The study was guided by the following research questions:

a) To what extent are OTM students equipped for work preparation with word processing application in polytechnics in Delta State

b) To what extent are OTM students equipped for work preparation with a database management system for job preparation in polytechnics in Delta State?

c) To what extent is webpage design application utilized for instructional delivery in Delta State Polytechnics?

\section{Research Hypothesis}

The following hypotheses were tested at, 0.05 level of significance.

a) There is no significant difference between the mean rating of male and female students on the use of information and communication technology application for job preparation of office technology and management students in polytechnics in Delta State

b) There is no significant difference between the mean rating of ND and HND, OTM students on the use of information and communication technology applications for job preparation of office technology and management students in polytechnics in Delta State.

\section{Review of Related Literature}

Information and Communication Technology (ICT) is an invention that has been accepted globally and its impact has been well felt, as it has led to various innovations in science, technology, and management of educational institutions. There is no universally acceptable definition of ICT for the fact that the concept, methods, and applications involved in ICT are evolving constantly on almost daily basis. Nweke (2013), has posited that ICT is the whole range of technologies that are applied in information processing and electronic communication. Milken (1999) in Emehi (2016), defines ICT as computer-based tools used by people to work with the information and communication processing needs of an organization. To Butcher (2003), posited that ICT is an electronic device used for collecting, storing, processing and communicating information.

\section{Concept of Office Technology and Management (OTM)}

The need for Information and Communication Technology (ICT), for teaching and learning, is in fact necessitated by the review of the old secretarial studies curriculum and the emergence of Office Technology and Management (OTM) curriculum. Resulting from this change, there comes the need for human competency and material resources as the lecturers who have been on ground require training to bridge the gap and meet up with the demand of the present technology and quality service delivery to the students of Office

Akpomedaye, E. (2019). Assessment of information and communication technology application in the teaching of office technology and management students in delta state polytechnics. International Journal of Social Sciences and 
Technology and Management (OTM). NBTE (2006), OTM program was designed to equip students with effective work competencies i.e. with secretarial/office skills for employment in various fields of endeavor. Similarly, OTM program according to Okoro (2009), incorporates the following six components in its design: office application, office technology, business, and administrative management, numeric components, general studies and Students Industrial Work Experience (SIWES). Office technology and management focus on combining office information technology skills with adequate and relevant business knowledge in solving organization's wide range of problem, (Akwajon \& Pwol, 2009).

In addition, Baba \& Akarahu (2012), opined that OTM program came into being for two reasons; first as a response to the yearning of the secretarial studies students and practitioners on the need to change the name of the program as their products are only suitable for traditional environment. Secondly and most importantly, as a result of change in curriculum by NBTE. From the views above, the OTM program is designed to alleviate the rate of unemployment among the graduates of secretarial studies and equip them with the competencies needed in facing the challenges of modern office machines and procedures.

\section{The Relevance of ICT and Education}

The various ICT packages used in the teaching-learning process in schools according to Ofodu (2007), include; radio, television, computers, overhead projectors, optical fibres, fax machine, CD-ROM, internet, electronic notice boards and continuously emerging state-of-the-act PCs, mobile phones, PDAs, palmtops, etc. The United Nation Education and Scientific Children Organization (UNESCO, 2009) posited that the use of ICT in education is rapidly expanding in many countries and is equally seen worldwide as an opportunity, that is equally necessary. Information and communication technology (ICT), is therefore concerned with using technology to gather and distribute information, and such information can be assessed by the intended user from any part of the world. ICT packages will make students be more independent in their learning, actively involved in their learning processes, be more creative and be highly challenged in their learning activities (UNESCO, 2009).

\section{Results and Discussions}

Data Presentation and Analysis

Table 1

Frequency distribution of respondents by gender

\begin{tabular}{lll}
\hline Gender & Frequency & Percentage (\%) \\
\hline Male & 120 & 42 \\
Female & 165 & 58 \\
Total & 285 & 100 \\
\hline
\end{tabular}

Source: Field Survey (2019)

The table above reveals that a total of two hundred and eighty-five OTM students took part in the study, out of which one hundred and twenty (120) students representing $42 \%$ were male while the other (165) representing $58 \%$ were female.

Table 2

Frequency distribution of respondents by qualification

\begin{tabular}{lll}
\hline Gender & Frequency & Percentage (\%) \\
\hline ND II & 150 & 53 \\
HND II & 135 & 47 \\
Total & 285 & 100 \\
\hline
\end{tabular}

Source: Field Survey (2019) 
Table 2 above shows that out of two hundred and eighty-five students that took part in the study, one hundred and fifty (150) representing 53\% were ND II students. The remaining one hundred and thirty-five respondents representing $47 \%$ were HND II students. The implication of this analysis is that more ND students were involved in the study than HND students.

Research Question 1

To what extent are OTM students equipped for work preparation with word processing competencies?

Table 3

Respondents rating of word processing competencies

\begin{tabular}{lllll}
\hline S/N & Word Processing Competencies & X & SD & Remarks \\
\hline 1 & Accessing the application and program & 3.20 & 0.81 & High Extent \\
2 & Adjusting documents margins & 2.90 & 0.51 & High Extent \\
3 & Creating and organizing computer files and folders & 2.80 & 0.88 & High Extent \\
4 & Using storage devices (CD, Flash, Diskette etc) & 3.80 & 0.99 & High Extent \\
5 & Correcting using program facilities to edit documents & 3.40 & 0.82 & High Extent \\
6 & Inserting pictures and symbols into a document with correct margin & 3.60 & 0.89 & High Extent \\
& and layouts & 3.60 & 0.97 & High Extent \\
7 & Changing font type, style, and size in a document & 3.60 & 0.96 & High Extent \\
8 & Creating font type, style, and size in a document & 2.70 & 0.82 & High Extent \\
9 & Using word act to create and shapeless in a document & 2.70 & 0.82 & High Extent \\
10 & Creating naming and renaming files & 3.60 & 0.99 & High Extent \\
11 & Using suitable commands to save files & 3.60 & 0.78 & High Extent \\
12 & Previewing and printing whole or part of the document & 3.00 & 0.88 & High Extent \\
13 & Suitably using bullets and numbers for itemization in a document & 3.00 & 0.90 & High Extent \\
& Grand mean & & &
\end{tabular}

Source: Field Survey (2019)

The data in table 3 revealed that OTM students are equipped with word processing application competencies for job preparation in polytechnics in Delta State. As can be seen on the table, all the items have mean ratings greater than 2.50. This implies that the respondents considered themselves equipped to a high extent with all the items on word processing application competencies for job preparation.

Research question 2

To what extent are OTM students equipped for work preparation with a database management system for job preparation in polytechnics in Delta State?

To answer this research question 2, the mean and standard deviations were, calculated from the frequency distributions of the respondents. The result is shown in table 4

Table 4

Respondents rating of the data management system

\begin{tabular}{lllll}
\hline S/N & Database management system & $\mathrm{X}$ & SD & Remarks \\
\hline 1 & Opening of database management application & 2.80 & 0.99 & High Extent \\
2 & Creating new tables using table wizard or design new & 2.30 & 0.94 & Low Extent \\
3 & Modifying table structure & 1.60 & 0.87 & Low Extent \\
4 & Applying data types and changing table format & 2.20 & 0.78 & Low Extent \\
5 & Locating a specific record in a database & 2.00 & 0.83 & Low Extent \\
6 & Adding and deleting fields and records & 2.00 & 1.80 & Low Extent \\
7 & Finding and replacing data in a database & 1.80 & 0.86 & Low Extent \\
8 & Sorting records in alphabetical or descending order & 2.00 & 1.00 & Low Extent \\
\hline
\end{tabular}

Akpomedaye, E. (2019). Assessment of information and communication technology application in the teaching of office technology and management students in delta state polytechnics. International Journal of Social Sciences and Humanities, 3(3), 18-27. https://doi.org/10.29332/ijssh.v3n3.342 


\begin{tabular}{lllll}
\hline 9 & Querying a table and applying filter & 2.00 & 1.00 & Low Extent \\
10 & Applying techniques for saving a new database & 1.80 & 0.89 & Low Extent \\
& Grand mean & 2.24 & 0.90 & Low Extent \\
\hline
\end{tabular}

Source: Field Survey (2019)

Nine out of ten competency items on database publishing were considered low extent with a mean rating below 2.50, while the remaining one item was rated high with a mean rating of 2.50. This shows that OTM students were not well equipped with database publishing application competencies for the world of work.

Research Question 3

To what extent are OTM students equipped for work preparation with Internet competencies for job preparation in polytechnics in Delta State?

Table 4

Respondents rating of internet competencies

\begin{tabular}{lllll}
\hline S/N & Internet Competencies & X & SD & Remarks \\
\hline 1 & Accessing webpage design application software or web browser & 3.80 & 0.94 & High Extent \\
2 & Creating an e-mail account & 3.60 & 0.74 & High Extent \\
3 & Opening and composing mail online & 2.60 & 0.92 & High Extent \\
4 & Sending and receiving mails with attachment & 3.20 & 0.81 & High Extent \\
5 & Typing and formatting a hypertext mark-up language (HTML) code & 3.00 & 0.78 & High Extent \\
6 & Applying background colour to a HTML element & 2.80 & 0.88 & High Extent \\
7 & Ability to use shared devices within a network & 3.20 & 0.84 & High Extent \\
8 & Refreshing, saving and publishing a webpage in a local and search & 3.40 & 0.76 & High Extent \\
& engines & & & \\
9 & Embedding an image into a webpage and aligning images to other & 3.60 & 0.89 & High Extent \\
& content of a webpage & & & \\
10 & Uploading and downloading of information from an into the internet & 2.70 & 0.88 & High Extent \\
11 & Prints a webpage document & 2.70 & 0.88 & High Extent \\
& Grand Total & 3.20 & 0.85 & High Extent \\
\hline
\end{tabular}

Source: Field Survey (2019)

The data above shows that the students considered themselves well equipped for job preparation in Webpage design.

\section{Summary}

This study ascertained the assessment of ICT application competencies possessed by Office Technology and Management (OTM) students for job preparation in Delta State Polytechnics. Specifically, the study was carried out to ascertain word processing, database management system and webpage design application competencies possessed by students for job preparation in polytechnics in Delta State.

The major findings from the analysis of data collected from the study are as follows:

a) Office technology and management students were equipped to a high extent with word processing application for job preparation in polytechnics in Delta State.

b) Office technology and management students are well equipped to a high extent with webpage design application for job preparation in polytechnics in Delta State

c) Office technology and management students are equipped to a low extent with database management application for job preparation in polytechnics in Delta State

d) There is no significant difference between the mean rating of male and female students in the use of information and communication technology application for job preparation of OTM students in polytechnics in Delta State 
There is no significant difference between the mean rating of ND and HND OTM students in the use of information and communication technology application for job preparation of office technology and management students in polytechnics in Delta State

\section{Conclusion}

It is obvious that Information and communication technology (ICT), is an indispensable tool in the development of quality learning in the educational system all over the world. Based on the finding of this study, it is therefore concluded that office technology and management students in polytechnics in Delta State are well equipped with information and communication technology in the areas of word processing and webpage design. However, office technology and management students are equipped to low extent in database management application for job preparation. The implication of this is that the employers of labour may consider graduates of OTM appropriate when the job requires the use of Database management application competency

\section{Recommendations}

Based on the findings of this study, discussion and conclusion drawn from it, the following recommendations are made:

1) Nigerian polytechnics should provide necessary instructional facilities such as the ones used in the automated offices and trained personnel for the proper training of skilled manpower to meet the standard set by the employers of secretaries in the automated office.

2) Database management applications and other ICT packages in the OTM curriculum should be emphasized in order to equip students with all the competencies that will ensure effective work performance on graduation.

3) Office laboratories in OTM departments should be equipped with modern office equipment needed for effective teaching and learning of database management applications. This is to ensure that knowledge acquired in school by OTM graduates would be relevant in the business offices where they are expected to work.

4) The stakeholders should build a support system for OTM graduates so that they can acquire all the expertise and competencies needed in the world of work.

5) The government should provide adequate computers and ICT facilities with the various packages installed for the teaching of OTM courses in polytechnics in Delta state.

6) The government should also send the OTM lecturers to further training to acquire the necessary skills needed to utilize the various computer packages for effective instructional delivery.

7) School authorities should make sure that the computer and ICT facilities in the school are in good conditions with a constant power supply for effective use during the instructional process.

Acknowledgments

I acknowledge the editor of IJSSH for their valuable time and support in completing the current paper.

Akpomedaye, E. (2019). Assessment of information and communication technology application in the teaching of office technology and management students in delta state polytechnics. International Journal of Social Sciences and

Humanities, 3(3), 18-27. https://doi.org/10.29332/ijssh.v3n3.342 


\section{References}

Abonyi, E. U. (2014). The use of ict in the teaching and learning of oral english in secondary.

Adetunji, A., Adetunji, A., Adeleke, E., \& Madubuike, S. (2017). Deregulation: the effect of market-led approach to Nigerian universities management. International Journal of Social Sciences and Humanities, 1(1), 1-8. https://doi.org/10.29332/ijssh.v1n1.6

Akwajon, C. \& Pwol, D. (2009). Entrepreneurship opportunities in office technology and Management. Secretarial forum, 4 (1), 54-62

Annan, D. (2005). Technologies for education: Potentials, Parameters and prospects. Washion publishing for education development, 1(6), 22-136.

Baba, E. I., \& Akarahu, C. U. (2012). Adequacy of educational resources for office technology and management programme in polytechnics in Kogi State. Business Education Journal, 8(2), 198-208.

Briones, VFV, Entenza, NP, Gámez, MR, \& Cedeño, MR (2016). Management model for university cooperation at Technical University of Manabí, Ecuador. International Research Journal of Management, IT and Social Sciences , 3 (9), 1-8.

Butcher, N. (2003). Technological infrastructure and use of ICT in education in Africa: An overview. Association for the Development of Education in Africa.

Ede, E. O. (2010). Assessment of Internet-Browsing skills of Undergraduates of University of Nigeria Nsukka.Preparing for the 21st Century globalization. In International Journal of Educational Research, 10(2), 30-37.

Egbe, C. I. (2010). Globalization and English language education in Nigeria: A rethink of English language curriculum content for secondary schools. International Journal of Educational Research, 10(2), $162-171$.

Emehi, A. (2017). Assessment of information and communication technology application in the teaching of OTM courses in delta state polytechnics. A Report Submitted To The Department Of Business Education, University Of Benin.

Ihimekpen, J. (2009). Current issues and trends in business teacher education: The technological implication. Book of Readings in Business Education 1(9), 104-109

Lawrence, U. C. (2010). Computer made easy. Nkpor: Sir Law Publishing Co. National Board for Technical Education (2004). Office technology and management curriculum and course specifications. Kaduna: NBTE.

Mashon, R. S., Nair, S., Sawant, P., Colah, R. B., Ghosh, K., \& Das, S. (2013). Hemoglobin Fontainebleau [a21 (B2) Ala> Pro]: The second report from India. Indian journal of human genetics, 19(3), 352.

Milken, M. (1999). Prosperity and Social Capital. Wall Street Journal, 23.

Mora, M. L. C., \& Triana, M. S. F. (2018). The Management of Process of the Budget Area. International Research Journal of Management, IT and Social Sciences, 5(2), 104-112.

Nweke, O. M. (2013). Appraisal of the level of utilization of ICT facilities in teaching OTM in South-Eastern polytechnics of Nigeria. A master Degree Thesis submitted to the Department of Vocational Education, NAU, Awka

Ofodu, G. O. (2007). Nigeria literacy educators and their technological needs in a digital age. Education Focus, 1(1), 22-30.

Okoro, F. C. (2009). The impact of non-oil export on the Nigerian economy. Lagos: Evans Publishers.

UNESCO, E. F. (2004). Global Monitoring Report 2003/4. Table, 2, 50.

Unesco. (2009). Policy guidelines on inclusion in education. 


\section{Biography of Author}

\begin{tabular}{|l|l||}
\hline \hline & $\begin{array}{l}\text { Emehi Akpomedaye. ND, BSc, PGDE, M. Éd, MNIM. TRCN. Dept of office technology } \\
\text { and management, school of business studies, Delta State Polytechnic, Ozoro, Delta } \\
\text { State. 09068147559 } \\
\text { Email: emehiakpomadaye2019@gmail.com }\end{array}$ \\
\hline
\end{tabular}

Akpomedaye, E. (2019). Assessment of information and communication technology application in the teaching of office technology and management students in delta state polytechnics. International Journal of Social Sciences and Humanities, 3(3), 18-27. https://doi.org/10.29332/ijssh.v3n3.342 